\title{
Centralized, nationwide electronic health records schemes under assault
}

$\mathrm{C}$ anada should revisit its electronic health records (EHRs) strategy in the wake of British recommendations that its similar blueprint should be jettisoned as wasteful and flawed, experts say.

The reports from the United Kingdom reinforce concerns that Canada Health Infoway's blueprint may not be practical or achievable, says Norm Archer, professor emeritus/special advisor at the eBusiness Research Centre at McMaster University in Hamilton, Ontario. "They should not try to implement it in the short term. To set out with a highly centralized system and try to extend it downwards [towards patients and clinicians] doesn't work."

But Archer worries that Infoway may have locked itself into its vision and current approach toward the development of EHRs as a result of signing contracts with information technology firms.

The UK government appears to be precisely in that bind in the face of recommendations that the nation's Department of Health scuttle its £7-billion effort to build an individual electronic care record for all National Health Service patients.

The UK's Public Accounts Committee argued that the ambitious plan should be abandoned. It "has proved beyond the capacity of the Department to deliver and the department is no longer delivering a universal system. Implementation of alternative up-todate IT [information technology] systems has fallen significantly behind schedule and costs have escalated," the committee said in a report, The National Programme for IT in the NHS: an update on the delivery of detailed care records systems (www.publications .parliament.uk/pa/cm201012/cmselect /cmpubacc/1070/107002.htm). Among the deficiencies identified by the committee were "weak" program manage-

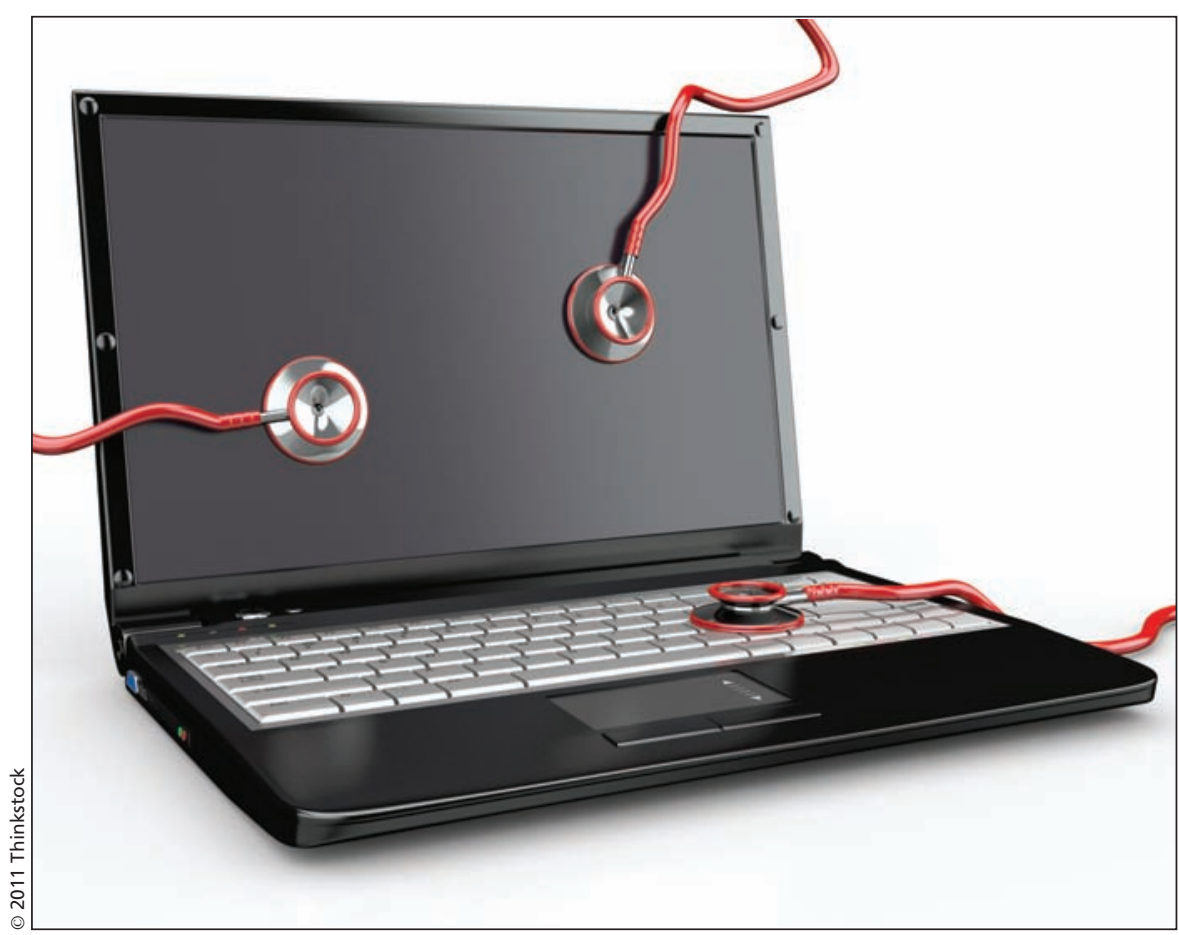

A pair of parliamentary committees in the United Kingdom have delivered a negative diagnosis for the the Department of Health's f7-billion effort to build an individual electronic care record for all National Health Service patients.

ment, overpayment of suppliers and inadequate financial oversight.

Equally withering was a UK Public Administration Select Committee report, Government and IT - " a recipe for rip-offs": time for a new approach, which concluded that the government essentially does not know how to develop information technology systems or judiciously shop for either hardware or software. "IT procurement has too often resulted in late, over budget IT systems that are not fit for purpose," states the report (www.publications .parliament.uk/pa/cm201012/cmselect /cmpubadm/715/715i.pdf).

The UK Department of Health has already spent roughly $£ 2.7$ billion on its electronic medical records plan, with the bulk of the money having been awarded to major software firms such as Accenture, Fujitsu, Computer Sciences Corporation and BT Software Company.
"We found that government is currently over-reliant on a small 'oligopoly' of large suppliers, which some witnesses referred to as a 'cartel'. Whether or not this constitutes a cartel in legal terms, current arrangements have led to a perverse situation in which governments have wasted an obscene amount of public money. Benchmarking studies have demonstrated that government pays substantially more for IT when compared to commercial rates," the Public Administration Select Committee report states.

The Auditor General of Canada has similarly criticized Canadian information technology procurement, most recently in the 2011 June Status Report of the Auditor General of Canada (www.oag-bvg.gc.ca/internet/English /parl_oag_201106_02_e_35370.html).

But it's unclear whether Infoway is bound by contracts similar to those 
which now may have tied the hands of the UK, as the crown corporation is not subject to financial disclosure rules that obligate it to disclose contracts or salary information.

What is clear, though, is that the bulk of Infoway monies have been invested in large IT systems. Only $17 \%$ of its $\$ 2.1$ billion in outlays since 2001 have been earmarked for clinician-level implementation,

"The bigger the project, the less likely it is to be successful," Archer notes, pointing to the $\$ 100$-million Ontario Laboratory Information System, which was cofunded by Infoway and the province, as an example of a large system that has delivered disappointing results.

Critics contend that IT procurement problems are compounded when governments seek to develop massive health information systems, such as Infoway's blueprint, which calls for an EHR available nationwide "anywhere, anytime in support of high quality care."

Infoway's vision is in the "same genre" as the UK's failed master plan, says Dr. Trisha Greenhalgh, professor at the Royal London School of Medicine and Dentistry, who has reviewed Canada's blueprint.

National-scale systems such as those espoused by the UK and Infoway "are likely to be less efficient, less costeffective, less safe, and the information they contain less trusted than smaller, more local systems," Greenhalgh says.

France has learned that lesson and recently abandoned its centralized EHR plan, notes Karl Stroetmann, author of a recent pan-European survey of e-health progress commissioned by the European Commission (http://ehealth-strategies.eu /report/eHealth_Strategies_Final_Report _Web.pdf). "They made little progress and have now stopped the whole project," he says. "They're starting again from scratch."

"Eyecatching" large systems of the ilk pursued by the UK and Canada are the product of a "top-down enthusiastdrive approach," and are crafted with "insufficient engagement of clinical users," says Dipak Kalra, professor of health informatics at University Col- lege London. The UK scheme was "over-ambitious in areas where there was little evidence and no experience to build upon."

Neither the UK's Department of Health nor Prime Minister David Cameron's government has responded to the Parliamentary calls for the jettisoning of Britain's EHR initiative. But the Department of Health said in response to a scathing National Audit Office report, The National Programme for IT in the NHS: an update on the delivery of detailed care records systems (www.nao.org.uk//idoc.ashx?doc $\mathrm{Id}=\mathrm{b} 2171 \mathrm{~d} 57-3120-40 \mathrm{a} 6-$ abe4-84b878 cbf $35 \mathrm{c} \&$ version $=-1$, response contained within the report) that its investments "will potentially deliver value for money" because reforms to the "future architecture of the programme" will allow "many sources of information to be connected together as opposed to assuming that all relevant information will be stored in a single system." Paul Christopher Webster, Toronto, Ont.

CMAJ 2011. DOI:10.1503/cmaj.109-4001 